\title{
OPTIMIZING ET-BASED IRRIGATION SCHEDULING FOR WHEAT AND MAIZE WITH WATER CONSTRAINTS
}

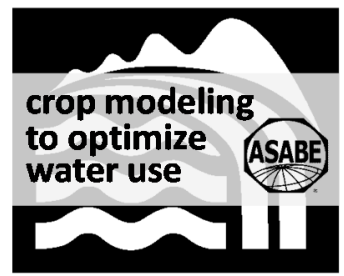

\author{
Q. X. Fang, L. Ma, Z. Qi, Y. J. Shen, L. He, S. H. Xu, \\ I. Kisekka, M. Sima, R. W. Malone, Q. Yu
}

\begin{abstract}
Deficit irrigation has been shown to increase crop water use efficiency (WUE) under certain conditions, even though the yield is slightly reduced. In this study, the Root Zone Water Quality Model (RZWQM) was first calibrated with measured data from a large weighing lysimeter from 1998 to 2003 at the Yucheng Experimental Station in the North China Plain for daily evapotranspiration (ET), soil water storage (0-120 cm), leaf area index (LAI), aboveground biomass, and grain yield. The calibrated model was then used to explore crop responses to ET-based irrigation management using weather data from 1958 to 2015 and identify the most suitable ET-based irrigation schedules for the area. Irrigation amount was determined by constraining irrigation to a percentage of potential crop ET $\left(40 \%, 60 \%, 80 \%\right.$, and $\left.100 \% E T_{c}\right)$ at the various growth stages of wheat [planting to before winter dormancy $(P-D)$, green up to booting $(G-B)$, booting to flowering $(B-F)$, and flowering to maturity $(F-M)]$ and of maize [planting to silking $(P-S)$ and silking to maturity $(S-M)]$, subject to seasonal water availability limits of 100/50,200/100,300/150, and 400/200 mm and no water limit for wheat/maize seasons, respectively. In general, wheat was more responsive to irrigation than maize, while greater influence of weather variation was simulated on maize than on wheat. For wheat with seasonal water limits, the highest average WUE was simulated with the highest targeted $E T_{c}$ levels at both the G-B and B-F stages and lower targeted ET $T_{c}$ levels at the P-D and F-M stages. However, the highest average grain yield was simulated with the highest targeted $E T_{c}$ levels at all four growth stages for no water limit and the $400 \mathrm{~mm}$ water limit, or at both the G-B and B-F stages for the 300 and $200 \mathrm{~mm}$ water limits. For maize, lower targeted ET $T_{c}$ levels after silking did not significantly affect maize production due to the high season rainfall, but irrigation of $60 \%$ ET $T_{c}$ before silking was recommended. These results could be used as guidelines for precision irrigation along with real-time weather information.
\end{abstract}

Keywords. Deficit irrigation, Evapotranspiration, Growth stage, RZWQM, Water use efficiency, Wheat and maize.

Submitted for review in March 2017 as manuscript number NRES 12363; approved for publication as part of the "Crop Modeling and Decision Support for Optimizing Use of Limited Water" Collection by the Natural Resources \& Environmental Systems Community of ASABE in September 2017.

Mention of company or trade names is for description only and does not imply endorsement by the USDA. The USDA is an equal opportunity provider and employer.

The authors are Quanxiao Fang, Professor, College of Agronomy, Qingdao Agricultural University, Shandong, China, and State Key Laboratory of Soil Erosion and Dryland Farming on the Loess Plateau, Institute of Soil and Water Conservation, CAS \& MWR, Yangling, China; Liwang Ma, Research Scientist, USDA-ARS Rangeland Resources and Systems Research Unit, Fort Collins, Colorado; Zhiming Qi, ASABE Member, Assistant Professor, Department of Bioresource Engineering, McGill University, Ste-Anne-de-Bellevue, Quebec, Canada; Yanjun Shen, Professor, Center for Agricultural Resources Research, Chinese Academy of Sciences, Shijiazhuang, China; Liang He, Research Assistant, National Meteorological Center, Beijing, China; Shouhua Xu, Research Assistant, State Key Laboratory of Soil Erosion and Dryland Farming on the Loess Plateau, Northwest A\&F University, Yangling, China; Isaya Kisekka, ASABE Member, Assistant Professor, Department of Land, Air, and Water Resources, University of California, Davis, California; Matthew Sima, Department of Biology, Duke University, Durham, North Carolina; Robert W. Malone, ASABE Member, Agricultural Engineer, USDA-ARS National Laboratory for Agriculture and the Environment, Ames, Iowa; Qiang Yu, Professor, State Key Laboratory of Soil Erosion and Dryland Farming on the Loess Plateau, Institute of Soil and Water Conservation, Northwest A\&F University, Yangling, China; Corresponding author: Quanxiao Fang, Changcheng Road No. 700, Qingdao, Shandong, China; phone: 86-15953277840; e-mail: fangqx@igsnrr.ac.cn.

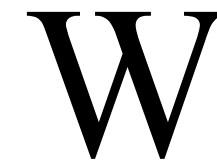
ater is the main limiting factor for crop yield in semiarid or water-limited areas, such as the North China Plain. Thus, irrigation is necessary to maintain high yield in such areas. As a result, excessive exploitation of groundwater and surface water is threatening the sustainability of agricultural production in these regions (Liu et al., 2001; Scanlon et al., 2012). Many studies have been carried out to investigate how to better manage limited irrigation water in arid or semiarid areas (Geerts and Raes, 2009; Fang et al., 2010a; Kang et al., 2017). Deficit or limited irrigation (Geerts and Raes, 2009; Du et al., 2015) has been evaluated for different crops, e.g., maize (Mansouri-Far et al., 2010; Gheysari et al., 2017) and wheat (Zhang et al., 2004; Tari, 2016). Deficit irrigation has also been scheduled based on various indicators, such as soil water balance, crop water stress indices, and evapotranspiration (ET), to increase water use efficiency (WUE) without substantially reducing crop yield (Hedley and Yule, 2009).

Identifying the most sensitive growth stages to water stress and the optimal irrigation levels (water stress intensity) at these growth stages are the keys to effectively applying deficit irrigation (Fereres and Soriano, 2007). In the North China Plain, Fang et al. (2007) found that a single irrigation at the jointing stage of wheat produced higher crop 
yield than applying water at the booting or grain filling stages based on a two-year field experiment. In the same region, Zhang et al. (2013) investigated the crop performance under limited water supply from 2005 to 2011 and found that a single irrigation after the recovering stage (green up) of wheat resulted in higher yield and WUE than water applied at planting for a good start of crop growth. In Nebraska, based on a two-year experiment at different irrigation levels (100\%, $75 \%, 60 \%$, and $50 \%$ of full irrigation treatment), Djaman and Irmak (2012) found that $60 \%$ or $75 \%$ of full irrigation treatment produced similar crop yield and WUE but saved $40 \%$ or $25 \%$ of the irrigation water, respectively, compared with the full irrigation treatment. In another study, Aydinsakir et al. (2013) found that the highest irrigation use efficiency was obtained for the $50 \%$ of full irrigation treatment, while the highest maize yield was produced under the $100 \%$ irrigation treatment. These field experiments provided useful guidelines for improving WUE with limited irrigation, but they showed high variability in crop yield and WUE due to variabilities of weather (especially precipitation), soil type, and agronomic practices across different regions (e.g., Zwart and Bastiaanssen, 2004; Fang et al., 2010a).

To address these issues, crop models have been used to explore deficit irrigation strategies for improving crop yield and WUE across various climate and soil conditions, such as APSIM (Kloss et al., 2012), AquaCrop (Steduto et al., 2009), CROPSYST (Marsal and Stöckle, 2012), DSSAT-CERESWheat (He et al., 2013), and RZWQM (Fang et al., 2010a; Saseendran et al., 2008). In an early study in California, Stöckle and James (1989) used CROPSYST to evaluate the effects of different irrigation schedules on maize yield and net income. They found that a slight water deficit produced higher net benefits than full irrigation, but severe deficits reduced grain yield obviously. In the North China Plain, irrigation schedules for wheat and maize were optimized for higher WUE and less decline in the groundwater table using long-term simulations with APSIM (Chen et al., 2010; Sun et al., 2015) and RZWQM (Fang et al., 2010b, 2013). Similar simulation studies on evaluating deficit irrigation strategies were carried out using the DSSAT-CERES-Maize model in the U.S. (He et al., 2013; Kisekka et al., 2016) and the AquaCrop model in Bolivia (Geerts et al., 2010). These studies, however, were generally based on fixed irrigation (amount and timing), and did not reflect the crop water requirement across seasons as influenced by weather variability and crop growth. ET-based irrigation schedules have rarely been studied in the North China Plain, especially using long-term simulations with agricultural system models. The objectives of this study were to use the calibrated RZWQM model to simulate crop water use and production in response to various ET-based irrigation levels at different growth stages of wheat and maize under different seasonal water limits, and to identify the optimal ET-based irrigation schedules for wheat and maize under seasonal irrigation water limits.
Table 1. Monthly precipitation $(\mathrm{mm})$ during the experimental period from 1998 to 2003 or averaged from 1958 to 2015 at the Yuncheng Experimental Station in the North China Plain.

\begin{tabular}{cccccccc}
\hline \multirow{5}{*}{ Crop } & Month & 1999 & 2000 & 2001 & 2002 & 2003 & Avg. \\
\hline Winter & Oct. & 9 & 61 & 104 & 29 & 9 & 39 \\
wheat & Nov. & 0 & 11 & 0 & 4 & 0 & 18 \\
& Dec. & 0 & 0 & 0 & 2 & 13 & 7 \\
& Jan. & 0 & 12 & 40 & 3 & 4 & 4 \\
& Feb. & 0 & 12 & 25 & 0 & 1 & 7 \\
& Mar. & 19 & 1 & 4 & 27 & 13 & 10 \\
& Apr. & 21 & 24 & 16 & 45 & 177 & 31 \\
& May & 55 & 23 & 3 & 44 & 15 & 40 \\
& June & 99 & 55 & 164 & 56 & 66 & 70 \\
\hline Maize & July & 78 & 182 & 92 & 43 & 143 & 174 \\
& Aug. & 24 & 198 & 37 & 19 & 84 & 125 \\
& Sept. & 33 & 107 & 81 & 43 & 49 & 61 \\
\hline
\end{tabular}

\section{Materials AND Methods}

\section{SITE DESCRIPTION}

The field experiments were conducted from 1998 to 2003 at the Yucheng Experimental Station in the North China Plain $\left(36^{\circ} 50^{\prime} \mathrm{N}, 116^{\circ} 34^{\prime} \mathrm{E}, 28 \mathrm{~m}\right.$ above mean sea level), one of 36 agricultural ecosystem stations of the Chinese Ecological Research Network (CERN). Wheat and maize are the main crops in the region and are generally rotated with each other. The growing season is from early October to early June of the next year for wheat and from mid-June to late September for maize. The silt loam soil is formed from sediments carried by the Yellow River and is rich in phosphorus and potassium. Detailed information on the experimental site can be found in Fang et al. (2010b, 2014a) and Yu et al. (2006). Annual mean air temperature and daily solar radiation at Yucheng from 1958 to 2015 was $13.7^{\circ} \mathrm{C}$ and $11.3 \mathrm{MJ}$ $\mathrm{m}^{-2} \mathrm{~d}^{-1}$, respectively.

Influenced by the monsoon climate, the area is characterized by high temperatures and high rainfall in the summer, with mean annual rainfall of $586 \mathrm{~mm}$ (1958 to 2015; table 1). Most of the rainfall ( $70 \%$ to $80 \%$ ) occurs from July to late September (maize season), while only $20 \%$ to $30 \%$ occurs from October to early June during wheat season, resulting in severe water deficits for wheat in the region (Fang et al., 2010a). The monthly rainfall from 1998 to 2003 is generally comparable with the long-term averaged data (table 1), except for the maize season in 2002 with rainfall of $105 \mathrm{~mm}$, which was lower than the average value $(360 \mathrm{~mm})$ for the area.

\section{LYSIMETER EXPERIMENT AND DATA MEASUREMENTS}

The large weighing lysimeter at the Yucheng Experimental Station has a surface area of $3.14 \mathrm{~m}^{2}(2 \mathrm{~m}$ interior diameter) and a cylindrical soil column to a depth of $5 \mathrm{~m}$ below the ground. The soil column weight was measured twice a day at 8:00 a.m. and 8:00 p.m. using a weighing system with a sensitivity of $60 \mathrm{~g}(0.02 \mathrm{~mm})$. The surface area of $3.14 \mathrm{~m}^{2}$ was used to calculate ET from the lysimeter, which may be smaller than the actual effective area of the lysimeter, especially during the middle to later growth stages and result in overestimation of ET, as discussed by Allen et al. (2011). A detailed description of the lysimeter experiment was given by Yang et al. (2007). Winter wheat (variety Zhixuan 1) and maize (variety Yedan 22) were planted in 
early October and mid-June, respectively. Management practices, such as planting density, tillage, irrigation, and fertilizer management, were similar across years according to the management practices of local farmers in the area. In general, three irrigations ( $>300 \mathrm{~mm}$ in total) were uniformly surface applied by hand at the planting, jointing, and booting stages of wheat, respectively, and one irrigation was applied at planting (about $80 \mathrm{~mm}$ ) for maize because rainfall was generally enough for maize growth. The total irrigation and rainfall were adequate for crop water requirements.

Soil water content in the $0-120 \mathrm{~cm}$ depth was measured with a neutron probe at $10 \mathrm{~cm}$ intervals in the middle of the lysimeter. Leaf area index (LAI) and aboveground biomass of the same crop in the field adjacent to the lysimeter were measured at five to seven day intervals. Final grain yield at harvest was measured in the lysimeter and in the field adjacent to the lysimeter. Detailed information on the data measurements can be found in Yu et al. (2006) and Liu and Luo (2010). Meteorological data, including daily minimum and maximum temperatures, relative humidity, rainfall, wind speed, and solar radiation, were collected from a meteorological station at the site. The measured lysimeter data from 1998 to 2003 were used in the study.

\section{RZWQM MODEL}

The Root Zone Water Quality Model (RZWQM2) with the DSSAT 4.0 crop modules were used in this study (Ma et al., 2006). The model uses the Green-Ampt equation to estimate infiltration and the Richards equation to estimate soil water redistribution. The modified Brooks-Corey equations (Brooks and Corey, 1964) were used to describe the soil water retention curve. Based on previous studies at the Yucheng Experimental Station (Yu et al., 2006; Fang et al., 2010b), we used soil water content at $333 \mathrm{kPa}$ to estimate BrooksCorey parameters, as described by Fang et al. (2014b). Soil hydraulic conductivity in the model can be estimated based on effective porosity (Ahuja et al., 1989) or from mean values of soil texture class (Rawls et al., 1982). Two water stress factors, turgor factor (TURFAC) and soil water factor (SWFAC), were calculated based on potential root water uptake and crop potential transpiration in the model, and the detailed calculations for the water stress factors can be found in Ma et al. (2006).

The model provides options to calculate daily potential evapotranspiration (PET) based on the Shuttleworth-Wallace method (Shuttleworth and Wallace, 1985), which is used as a surrogate for potential crop $\mathrm{ET}\left(\mathrm{ET}_{c}\right)$ to determine the irrigation requirement. Actual irrigation amount is calculated from a percentage of $\mathrm{ET}_{c}$ less the rainfall amount occurring between irrigation events and is also constrained by soil water holding capacity. Based on the results of an ETbased deficit irrigation experiment, Ma et al. (2012) found that the RZWQM2-simulated PET was consistent with the PET estimated from the reference ET and crop coefficient, and the simulated irrigation amounts and crop yield for these irrigation schedules were also in good agreement with measured data. The irrigation interval and seasonal amount limit can be set as inputs for the ET-based irrigation management

Table 2. Initial values, ranges, and final values of soil water content at $333 \mathrm{kPa}\left(\theta_{1 / 3}\right)$ and saturated hydraulic conductivity $\left(K_{\text {sat }}\right)$ used for calibrating RZWQM at the Yucheng Experimental Station.

\begin{tabular}{|c|c|c|c|c|c|c|c|c|}
\hline \multirow{2}{*}{$\begin{array}{c}\text { Soil Layer } \\
(\mathrm{cm})\end{array}$} & \multirow[b]{2}{*}{ Soil Type } & \multirow{2}{*}{$\begin{array}{c}\text { Bulk Density } \\
\left(\mathrm{g} \mathrm{cm}^{-3}\right)\end{array}$} & \multicolumn{3}{|c|}{$K_{\text {sat }}\left(\mathrm{cm} \mathrm{h}^{-1}\right)$} & \multicolumn{3}{|c|}{$\theta_{1 / 3}\left(\mathrm{~m}^{-3} \mathrm{~m}^{-3}\right)$} \\
\hline & & & Initial $^{[\mathrm{a}]}$ & Range & Final & Initial $^{[\mathrm{a}]}$ & Range & Final \\
\hline $0-10$ & Loam & 1.423 & 5.5 & 0.1 to 10 & 1.14 & 0.19 & 0.15 to 0.27 & 0.26 \\
\hline $10-30$ & Loam & 1.423 & 1.32 & 0.1 to 10 & 0.46 & 0.23 & 0.20 to 0.30 & 0.28 \\
\hline $30-60$ & Loam & 1.423 & 1.20 & 0.1 to 10 & 0.64 & 0.27 & 0.24 to 0.35 & 0.31 \\
\hline $60-90$ & Silty loam & 1.32 & 0.68 & 0.1 to 5 & 0.45 & 0.29 & 0.24 to 0.35 & 0.32 \\
\hline $90-120$ & Silty loam & 1.32 & 0.50 & 0.1 to 5 & 0.63 & 0.30 & 0.24 to 0.35 & 0.27 \\
\hline $120-180$ & Silty loam & 1.32 & 0.32 & 0.1 to 5 & 0.73 & 0.29 & 0.24 to 0.35 & 0.27 \\
\hline $180-250$ & Sandy loam & 1.42 & 0.32 & 0.1 to 5 & 1.35 & 0.25 & 0.20 to 0.30 & 0.21 \\
\hline
\end{tabular}

[a] Initial values and ranges based on previous studies at the Yucheng Experimental Station (Fang et al., 2010b, 2014a; and Yu et al., 2006).

Table 3. Initial and final values of crop cultivar genetic parameters for calibrating RZWQM at the Yucheng Experimental Station (values in parentheses are ranges used for calibration).

\begin{tabular}{|c|c|c|c|}
\hline & & Initial $^{[\mathrm{a}]}$ & Final (Range) \\
\hline \multicolumn{4}{|c|}{ Wheat parameters } \\
\hline $\mathrm{P} 1 \mathrm{~V}$ & Days at optimum vernalizing temperature required to complete vernalization (days). & 50 & $45(25$ to 70$)$ \\
\hline P1D & $\begin{array}{l}\text { Relative amount by which development is slowed when plants are grown in a photoperiod that is } \\
1 \mathrm{~h} \text { shorter than the optimum (photoperiod response parameter, } \% \text { ). }\end{array}$ & 60 & $57(25$ to 70$)$ \\
\hline P5 & Relative grain filling duration based on thermal time (degree days above a base temperature of $1^{\circ} \mathrm{C}$ ). & 430 & $440(400$ to 500$)$ \\
\hline G1 & Kernel number per unit weight of stem (less leaf blades and sheaths) plus spike at anthesis $\left(\mathrm{g}^{-1}\right)$. & 27 & $23(15$ to 45$)$ \\
\hline G2 & Kernel filling rate under optimum conditions $\left(\mathrm{mg} \mathrm{d}^{-1}\right)$. & 25 & $21(20$ to 35$)$ \\
\hline G3 & $\begin{array}{l}\text { Non-stressed dry weight of a single stem (excluding leaf blades and sheaths) and spike when } \\
\text { elongation ceases }(\mathrm{g}) \text {. }\end{array}$ & 1 & $2(0.5$ to 3$)$ \\
\hline PHINT & Phyllochron interval $\left({ }^{\circ} \mathrm{C}\right)$. & 85 & $80(75$ to 90$)$ \\
\hline \multicolumn{4}{|c|}{ Maize parameters } \\
\hline $\mathrm{P} 1$ & $\begin{array}{l}\text { Thermal time from seedling emergence to the end of juvenile phase during which the plants are } \\
\text { not responsive to changes in photoperiod (degree days). }\end{array}$ & 230 & $236(130$ to 300$)$ \\
\hline $\mathrm{P} 2$ & $\begin{array}{l}\text { Extent to which development is delayed for each hour increase in photoperiod above the longest } \\
\text { photoperiod at which development is at maximum rate. }\end{array}$ & 0.4 & $0.36(0.2$ to 0.7$)$ \\
\hline P5 & Thermal time from silking to physiological maturity (degree days). & 830 & $700(600$ to 1000$)$ \\
\hline $\mathrm{G} 2$ & Maximum possible number of kernels per plant. & 760 & $796(600$ to 1000$)$ \\
\hline G3 & Grain filling rate during the linear grain filling stage and under optimum conditions ( $\left.\mathrm{mg} \mathrm{d}^{-1}\right)$. & 6 & $8.5(4$ to 15$)$ \\
\hline PHINT & Phyllochron interval (degree days). & 39 & $38(35$ to 50$)$ \\
\hline
\end{tabular}


option in the model. The ET-based irrigation scheduling method was applied to derive better targeted irrigation levels for maize in northeastern Colorado (Fang et al., 2014b).

\section{Model Simulations}

The initial soil hydraulic parameters (table 2) and crop parameters (table 3) were based on previous studies at the Yucheng Experimental Station (Fang et al., 2010b, 2014a; Yu et al., 2006). Soil nutrient parameters were set according to Fang et al. (2010b). Because the model was calibrated at the Yucheng Experimental Station under different experimental treatments, these parameters were considered reasonable for the current experimental conditions. However, we manually adjusted these parameters within narrow ranges to further improve the model simulations using the trial-anderror method. Specifically, based on a previous study at the experimental site (Fang et al., 2010b), the model was first calibrated with measured data, including soil water content in the $0-120 \mathrm{~cm}$ depth, aboveground biomass, LAI, and grain yield, from the lysimeter experiment with full irrigation from 1998 to 2003. After calibration, the model-simulated daily ET values were compared with measured daily ET from the lysimeter during this period.

After calibration, the model was run from 1958 to 2015 under different deficit irrigation levels at different crop growth stages to investigate crop water use and production. Based on the crop growth phenology information (Xiao et al., 2013; Liu and Luo, 2010) and the common irrigation management by local farmers in the area, four growth stages were selected for winter wheat: planting to before winter dormancy (P-D), green up to booting (G-B), booting to flowering (B-F), and flowering to maturity (F-M). No irrigation was applied during the winter dormancy period. To account for the changes in these growth stages associated with weather variations, the long-term simulated dates for these wheat growth stages from 1958 to 2015 were used. Specifically, the simulated date from 1958 to 2015 for dormancy, green up, booting, flowering, and maturity were set as 61 to 72 days after planting (DAP) (4-17 December), 133 to 144 DAP (13-24 February), 180 to 194 DAP (3-17 April), 204 to 219 DAP (29 April to 12 May), and 235 to 246 DAP (27 May to 7 June), respectively. Similarly, for the maize seasons, two growth stages before and after the simulated silking date (6-12 August, 51 to 57 DAP) were selected. Initial soil water content at planting was set for each year at $70 \%$ field water capacity in the $0-120 \mathrm{~cm}$ soil depth, based on the averaged long-term simulations under rainfed condition from 1958 to 2015 , to eliminate its effects on soil water use and crop growth across seasons.

For the long-term simulations, winter wheat and maize were planted on 5 October and 15 June, respectively, each year and harvested on 7 June and 27 September, respectively, each year, according to the prevailing practice in the area. Furrow irrigation is the main irrigation method, adopted by about $70 \%$ of farmers in northern China (Blanke et al., 2007), and was implemented every five days during the selected growth stages according to a recent study on optimizing irrigation intervals for ET-based irrigation scheduling (Mbabazi et al., 2017). Other management information, such as planting density, row spacing, fertilizer application, and tillage, were set according to experimental management. Irrigation was scheduled to meet a certain percentage of crop potential ET $\left(\mathrm{ET}_{c}\right)$ demand estimated by the ShuttleworthWallace method (i.e., $40 \%, 60 \%, 80 \%$, and $100 \% \mathrm{ET}_{c}$ ) during the crop growth stages (four growth stages for winter wheat and two growth stages for maize). The number of scenarios was 256 for winter wheat (e.g., 40/40/40/40 denotes targeting $40 \% \mathrm{ET}_{c}$ during each of the four growth stages of wheat) and 16 for maize (e.g., 40/40 denotes targeting 40\% $\mathrm{ET}_{c}$ during planting to silking (P-S) and silking to maturity (S-M), respectively). These scenarios were simulated either without a seasonal irrigation limit or with seasonal water limits of 400, 300, 200, and $100 \mathrm{~mm}$ for wheat and 200, 150, 100 , and $50 \mathrm{~mm}$ for maize. The total scenarios were $256 \times$ $5=1024$ for wheat and $16 \times 5=80$ for maize. A program was developed to write the model input data for all these scenarios, which were run with the batch simulation option from the model interface.

\section{Statistical CRITERIA}

To evaluate the model performance, mean difference (MD), root mean squared error (RMSE), relative RMSE (RRMSE), Nash-Sutcliffe model efficiency (ME; Nash and Sutcliffe, 1970), and coefficient of determination $\left(R^{2}\right)$ were used.

\section{RESULT AND DISCUSSION \\ Model Calibration}

For model calibration, the simulated soil water storage (SWS) in 0-120 cm soil profiles showed good response to water inputs (rainfall plus irrigation) and similar trends with measured data in the lysimeter experiment from 1998 to 2003 (fig. 1a). The corresponding RMSE, $\mathrm{R}^{2}, \mathrm{ME}$, and RRMSE values for simulated SWS were $33 \mathrm{~mm}, 0.25,0.18$, and 0.10 , respectively (fig. 1a and table 4 ). SWS was oversimulated during the maize seasons (June to September in 2001), probably due to the under-simulated ET (fig. 1e). The under-simulated SWS during the winter (December to February) in 2001 and 2003 was consistent with a previous simulation study at the site (Fang et al., 2010b). The statistical results for simulated SWS in table 4 were comparable with the previous RZWQM simulation studies at the site with RMSE values of 30 to $50 \mathrm{~mm}$ (Yu et al., 2006; Fang et al., 2010b, 2014a).

The simulated aboveground biomass was close to the measured data across the crop seasons (fig. 1b), except for under-simulations for maize in 1999 and over-simulations for maize in 2001 and for wheat in 2002 during the calibrations. The simulated LAI values were generally higher than measured for the wheat seasons, especially during the later growth stages (fig. 1c). Similar simulation results with RZWQM at the experimental site were reported by Fang et al. (2014a). The simulated LAI values were closer to the measured data for the maize seasons than for wheat (fig. 1c). The overall RMSE, $\mathrm{R}^{2}$, ME, and RRMSE values from 1998 to 2003 were, respectively, $1979 \mathrm{~kg} \mathrm{ha}^{-1}, 0.87,0.86$, and 0.31 


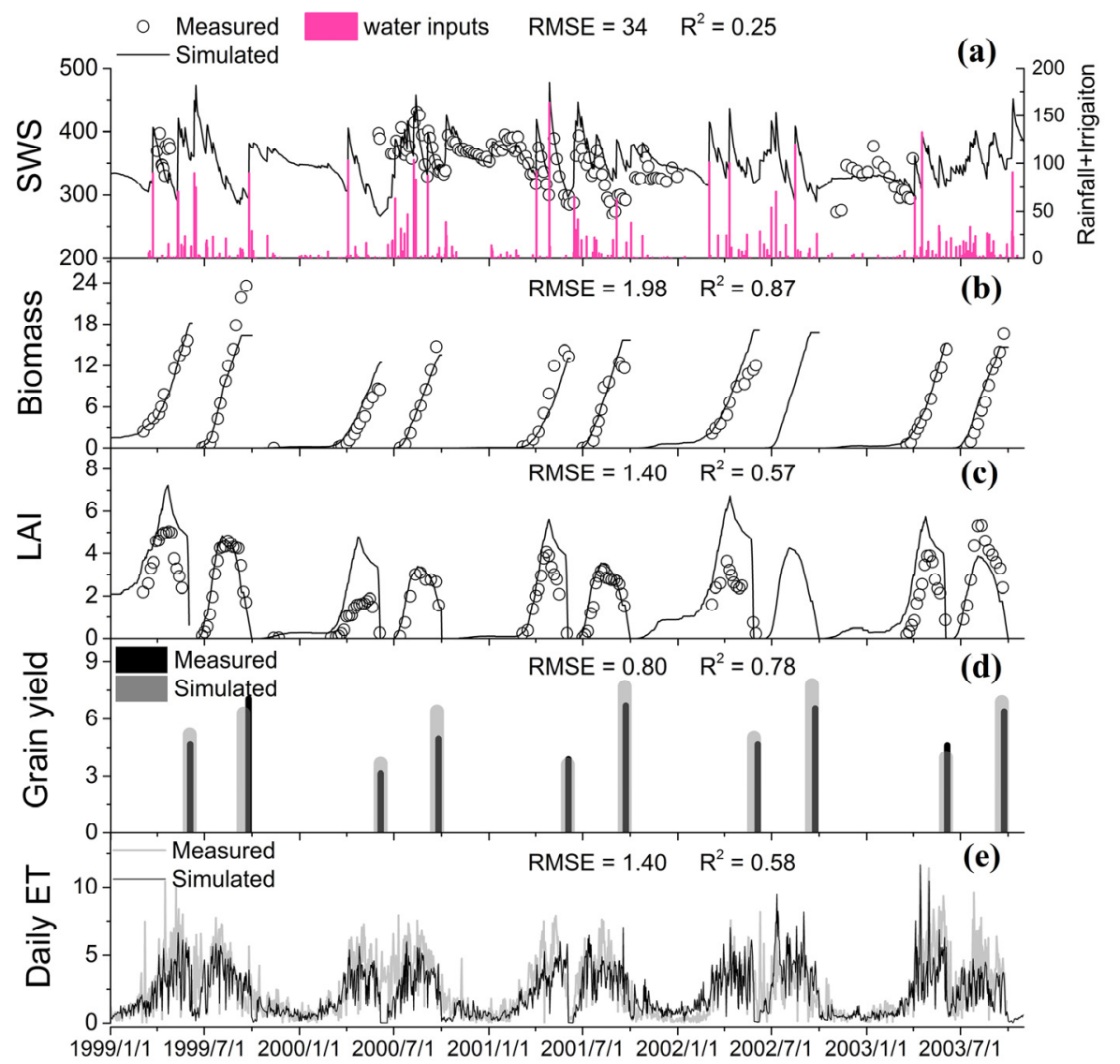

Figure 1. Comparisons between (a) soil water storage in 0-120 $\mathrm{cm}$ profile (SWS, mm), (b) aboveground biomass (Mg ha $\left.{ }^{-1}\right)$, (c) leaf area index (LAI, $\mathrm{m}^{2} \mathrm{~m}^{-2}$ ), (d) final grain yield $\left(\mathrm{Mg} \mathrm{ha}^{-1}\right)$, and (e) daily evapotranspiration (ET, $\mathrm{mm}$ ) simulated by RZWQM and observed from lysimeter experiments in wheat (January to June) and maize (July to October) rotations from 1998 to 2003 (water input includes rainfall and irrigation).

for aboveground biomass and $1.40 \mathrm{~m}^{2} \mathrm{~m}^{-2}, 0.57,-0.01$, and 0.60 for LAI (table 4). These results are comparable with previous simulation studies with RMSE values of 1500 to $3800 \mathrm{~kg} \mathrm{ha}^{-1}$ (RRMSE values of 0.23 to 0.47 ) for aboveground biomass and RMSE values of 0.88 to $1.34 \mathrm{~m}^{2} \mathrm{~m}^{-2}$ (RRMSE values of 0.38 to 0.87 ) for LAI at the site (Yu et al., 2006; Fang et al., 2014a).

Grain yield was slightly over-simulated by $360 \mathrm{~kg} \mathrm{ha}^{-1}$, with RMSE, $\mathrm{R}^{2}$, ME, and RRMSE values of $798 \mathrm{~kg} \mathrm{ha}^{-1}$, $0.78,0.60$, and 0.15 , respectively, for the calibration period from 1998 to 2003 (fig. 1d and table 4). Over-simulations occurred in the maize seasons of $2000(15 \%), 2001(29 \%)$, and 2002 (14\%) (fig. 1d). Similar crop yield simulations were previously obtained at the experimental site, with RMSE values of 455 and $950 \mathrm{~kg} \mathrm{ha}^{-1}$ for wheat and maize,

Table 4. Statistical results $(\mathrm{MD}=$ mean difference, $\mathrm{RMSE}=$ root mean square error, $\mathbf{R}^{2}=$ coefficient of determination, $M E=$ model efficiency, and RRMSE = relative RMSE) for RZWQM-simulated soil water storage (SWS, mm), leaf area index (LAI, $\mathrm{m}^{2} \mathrm{~m}^{-2}$ ), aboveground biomass (AGB, $\left.\mathrm{kg} \mathrm{ha}^{-1}\right)$, final grain yield (GY, $\left.\mathrm{kg} \mathrm{ha}^{-1}\right)$, and daily and seasonal evapotranspiration $(E T, \mathrm{~mm})$ based on lysimeter experiments from 1998 to 2003 at the Yucheng Experimental Station.

\begin{tabular}{cccccc}
\hline & MD & RMSE & $\mathrm{R}^{2}$ & ME & RRMSE \\
\hline SWS & 3 & 34 & 0.25 & 0.18 & 0.10 \\
LAI & 0.88 & 1.40 & 0.57 & -0.01 & 0.60 \\
AGB & 531 & 1979 & 0.87 & 0.86 & 0.31 \\
GY & 360 & 798 & 0.78 & 0.60 & 0.15 \\
Daily ET & -0.3 & 1.4 & 0.58 & 0.56 & 0.56 \\
Seasonal ET & -35 & 68 & 0.24 & -0.41 & 0.17 \\
\hline
\end{tabular}

respectively (Fang et al., 2014a; Yu et al., 2006). The simulated anthesis and maturity dates for both wheat and maize were close to the observed data for 1998 to 2003, with MD values of -1.1 and -3.6 days, respectively, which are comparable with the simulation results of Fang et al. (2010b).

The calibrated model produced daily ET values close to the 1998 to 2003 measured lysimeter data, with RMSE, R², and ME values of $1.4 \mathrm{~mm} \mathrm{~d}^{-1}, 0.58$, and 0.56 , respectively (table 4 and fig. 1e). A detailed comparison of the simulated

Table 5. Comparisons of daily evapotranspiration (ET, mm) simulated by RZWQM and measured by fully irrigated lysimeter experiments across different crop seasons from 1998 to $2003\left(\mathrm{ET}_{m}=\right.$ mean measured daily $\mathrm{ET}, \mathrm{ET}_{s}=$ mean measured simulated $\mathrm{ET}, \mathrm{MD}=$ mean difference, RMSE = root mean square error, $R^{2}=$ coefficient of determination, $\mathrm{ME}=$ model efficiency, and RRMSE $=$ relative RMSE).

\begin{tabular}{lccccccc}
\hline \multicolumn{1}{c}{ Crop Season } & $\mathrm{ET}_{m}$ & $\mathrm{ET}_{s}$ & $\mathrm{MD}$ & $\mathrm{RMSE}$ & $\mathrm{R}^{2}$ & $\mathrm{ME}$ & $\mathrm{RRMSE}$ \\
\hline 1999 & & & & & & & \\
$\quad$ Winter wheat & 1.97 & 1.74 & -0.23 & 1.09 & 0.75 & 0.71 & 0.56 \\
$\quad$ Maize & 3.55 & 3.26 & -0.28 & 1.14 & 0.62 & 0.59 & 0.32 \\
\hline 2000 & & & & & & & \\
$\quad$ Winter wheat & 1.81 & 1.60 & -0.21 & 0.86 & 0.75 & 0.73 & 0.48 \\
$\quad$ Maize & 4.20 & 3.05 & -1.15 & 1.60 & 0.49 & 0.03 & 0.38 \\
\hline 2001 & & & & & & & \\
$\quad$ Winter wheat & 2.12 & 1.70 & -0.42 & 1.18 & 0.67 & 0.62 & 0.56 \\
$\quad$ Maize & 3.50 & 3.21 & -0.29 & 1.55 & 0.30 & 0.19 & 0.44 \\
\hline 2002 & & & & & & & \\
$\quad$ Winter wheat & 1.61 & 1.88 & 0.27 & 0.94 & 0.71 & 0.68 & 0.58 \\
$\quad$ Maize & 2.85 & 3.66 & 0.81 & 1.50 & 0.44 & -0.35 & 0.53 \\
\hline 2003 & & & & & & & \\
$\quad$ Winter wheat & 2.23 & 1.74 & -0.49 & 1.11 & 0.86 & 0.80 & 0.50 \\
$\quad$ Maize & 3.14 & 2.49 & -0.65 & 1.87 & 0.22 & 0.10 & 0.60 \\
\hline
\end{tabular}


and measured daily ET is shown in table 5. The daily ET was generally under-simulated, as shown by the negative MD values, except for the wheat and maize seasons in 2002 (table 4). Similar results were reported by Fang et al (2014a), and high measured daily ET from the lysimeter may be due to several factors, such as "bloom effect" and errors in calculating the effective area of the lysimeter, as discussed by Allen et al. (2011). The daily ET was generally over-simulated during early wheat seasons (January to March) and later maize seasons (September to October) and under-simulated during middle to late wheat seasons and early maize seasons (fig. 1e). The RMSE and RRMSE values for the simulated daily ET across these seasons ranged from 0.86 to $1.87 \mathrm{~mm} \mathrm{~d}^{-1}$ and from 0.32 to 0.60 , respectively (table 5). This result is comparable with previous daily ET simulation results at the site, with RMSE (RRMSE) values of 1.80 to $2.64 \mathrm{~mm} \mathrm{~d}^{-1}$ (0.46 to 0.75 ) (Fang et al., 2014a) and 1.14 to $1.91 \mathrm{~mm} \mathrm{~d}^{-1}$ (0.47 to 0.65 ) (Yu et al., 2006). The inadequate simulation of daily ET for the maize seasons may be partly due to inaccurate soil moisture and crop growth simulations in the maize seasons (fig. 1). The lysimeter surface area $\left(3.14 \mathrm{~m}^{2}\right)$ used to calculate daily ET may be less than the effective area of canopy cover during August, which would also result in over-calculated ET in the lysimeter.

\section{OPTIMIZING ET-BASED IRRIGATION SCHEDULING IN WHEAT SEASONS \\ Unlimited Seasonal Water A vailability}

When deficit irrigation was applied at only one of the four growth stages during the wheat seasons, the simulated grain yields across the seasons generally increased with targeted $\mathrm{ET}_{c}$ levels at the G-B or B-F growth stages, but simulated yields increased only slightly with targeted $\mathrm{ET}_{c}$ levels at the P-D or F-M growth stages (fig. 2a). Similar results were obtained for simulated WUE across the seasons (fig. 2b), where simulated WUE decreased as the targeted $\mathrm{ET}_{c}$ levels increased at the P-D or F-M growth stages. Increasing the targeted $\mathrm{ET}_{c}$ levels (reducing water stress) at the four growth stages of wheat reduced the variations in simulated crop yield and WUE across seasons (fig. 2). Little or no reduction in simulated average wheat yield for the lowest (40\%) targeted $\mathrm{ET}_{c}$ level at the F-M growth stage was mainly due to
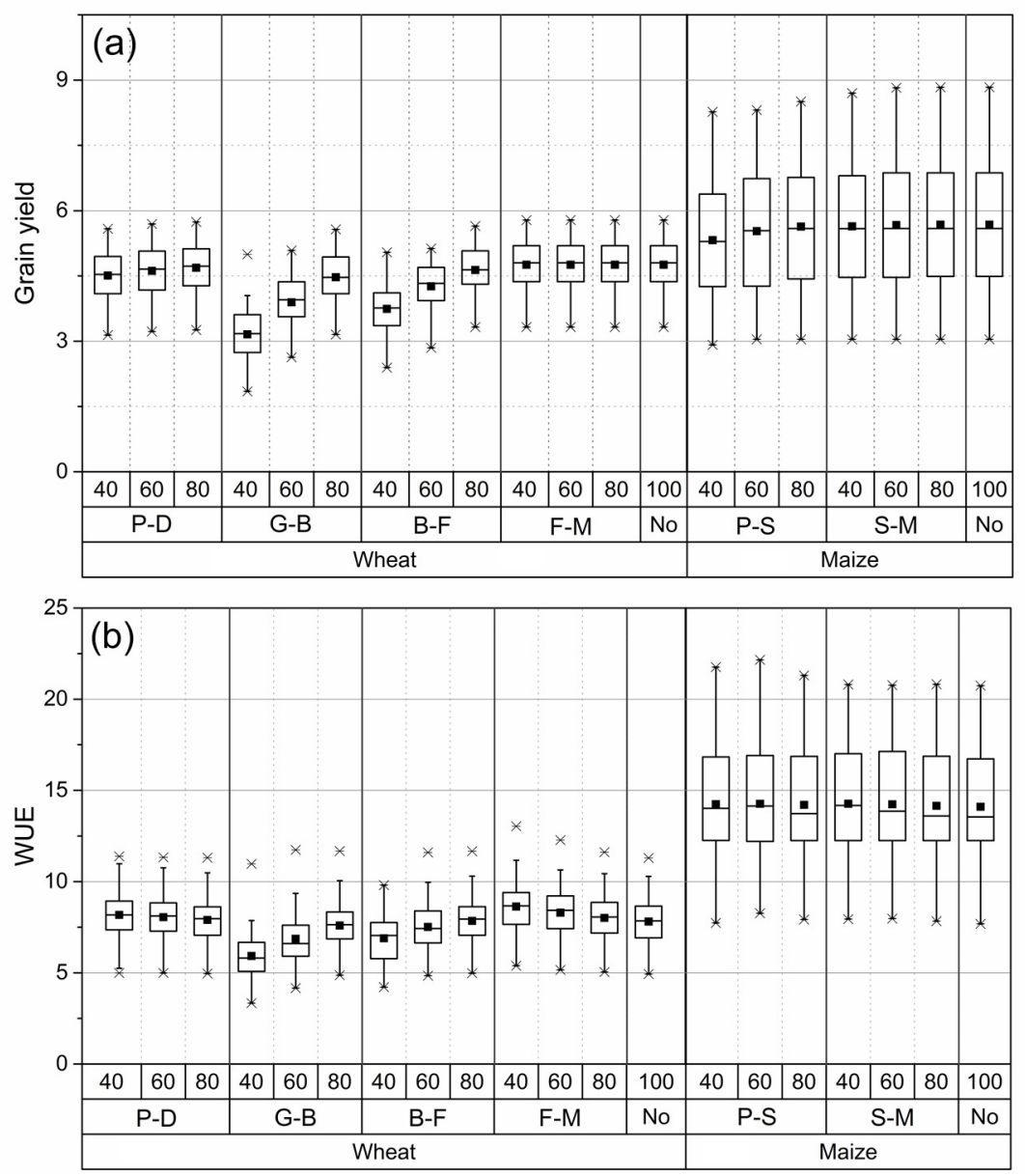

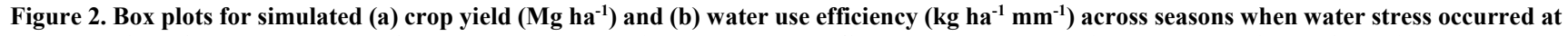
only one of the four growth stages for wheat $(\mathrm{P}-\mathrm{D}=$ planting to dormancy, $\mathrm{G}-\mathrm{B}=$ green up to booting, $\mathrm{B}-\mathrm{F}=\mathrm{booting}$ to flowering, and $\mathrm{F}-\mathrm{M}=$ flowering to maturity) or at one of the two growth stages for maize (P-S = planting to silking and $\mathrm{S}-\mathrm{M}=$ silking to maturity) based on long-term simulations for 1958 to 2015 under unlimited water conditions 40,60 , and 80 indicate targeted $40 \%$, $60 \%$, and $80 \%$ potential crop ET, and 100 indicates targeted $100 \%$ potential crop ET with no water stress for wheat and maize.The box plots show 5th, 25 th, 50 th, 75 th, and 95 th percentiles. The dots and lines in the boxes indicate the mean and median values across years, respectively. The crosses indicate the minimum and maximum values across years. 
the simulated moderate soil water content during the period (64\% field capacity averaged from 1958 to 2015 for the $100 / 100 / 100 / 40$ irrigation levels). This result was mainly due to the relatively high rainfall amounts during May and June (table 1) and high residual soil water content from the previous growth stage (B-F) with the $100 \%$ targeted $\mathrm{ET}_{c}$ level.

These results indicate that the winter wheat growth stages most sensitive to water stress were the middle stages (G-B and B-F). Field experiments also demonstrated that wheat growth was most sensitive to water stress at the jointing stage (Zhang et al., 1999; Fang et al., 2007) and the booting stage (Bian et al., 2016; Araya et al., 2017), while other experiments showed that limited irrigation at other growth periods (pre-planting or grain filling) produced high grain yield and WUE (Zhang and Oweis, 1999; Li et al., 2005). The growth stage most sensitive to water stress varied among these short-term (one to three years) experiments, as discussed by Fang et al. (2010a), and was demonstrated by the simulated high variations in crop yield and WUE across different seasons (fig. 2). Based on figure 2, reasonable irrigation levels for achieving both high crop yield and WUE should be at or above $80 \% \mathrm{ET}_{c}$ for the G-B and B-F growth stages and below $60 \% \mathrm{ET}_{c}$ for the P-D (early) and F-M (late) growth stages for wheat. In a previous field study on limited irrigation based on soil water deficit, Kang et al. (2002) also found that mild to severe soil water depletion at the early growth period and maturity of winter wheat was optimal for deficit irrigation scheduling in the Loess Plateau of China.

Contour plots (fig. 3) were used to explore the effects of these targeted $\mathrm{ET}_{c}$ levels at any two of the four growth stages on one crop variable (e.g., grain yield and WUE). The simulated average wheat yield across seasons increased from $1848 \mathrm{~kg} \mathrm{ha}^{-1}$ at targeted $40 \% \mathrm{ET}_{c}$ levels to $4829 \mathrm{~kg} \mathrm{ha}^{-1}$ at targeted $100 \% \mathrm{ET}_{c}$ levels at the four growth stages (fig. 3a). Much more increase in grain yield occurred with the targeted $\mathrm{ET}_{c}$ levels at the G-B and B-F stages than at the P-D and F$\mathrm{M}$ stages. Grain yield was greater than $4500 \mathrm{~kg} \mathrm{ha}^{-1}$ (white areas in fig. 3a) with targeted levels of $100 \% \mathrm{ET}_{c}$ at the G-B and B-F stages and with targeted levels of $40 \% \mathrm{ET}_{c}$ at the P$\mathrm{D}$ and F-M stages. The targeted $\mathrm{ET}_{c}$ levels at both the G-B and B-F stages to obtain grain yield higher than $4500 \mathrm{~kg}$ $\mathrm{ha}^{-1}$ were reduced to $60 \%$ to $80 \% \mathrm{ET}_{c}$ levels when irrigation at the other two stages (P-D and F-M) was increased to $100 \%$ $\mathrm{ET}_{c}$ (white areas in fig. 3a).

The simulated average irrigation requirement and ET
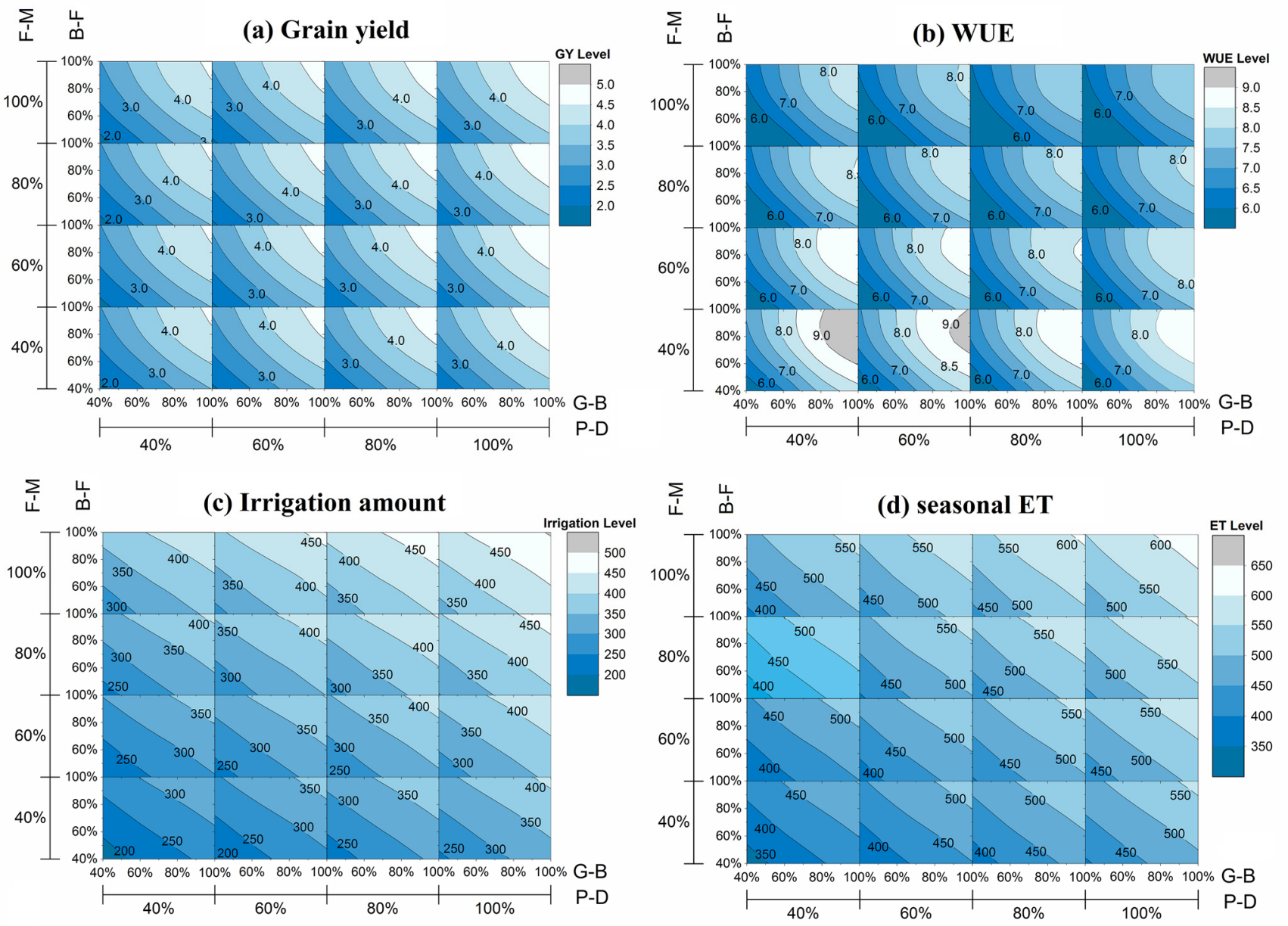

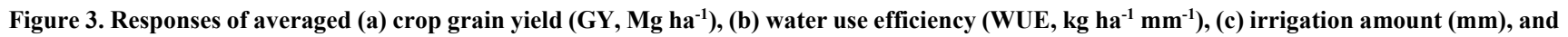
(d) evapotranspiration (ET, $\mathrm{mm})$ across seasons to the various targeted ET levels $(40 \%$ to $100 \%$ potential crop ET) at the four growth stages of wheat (P-D = planting to dormancy, G-B = green up to booting, $\mathrm{B}-\mathrm{F}=$ booting to flowering, and $\mathrm{F}-\mathrm{M}=$ flowering to maturity) based on long-term simulations for 1958 to 2015 under the no water limit condition. 
Table 6. The selected most reasonable irrigation schedules with mean values of irrigation amount, grain yield (GY), evapotranspiration (ET), and water use efficiency (WUE) when water stress occurred at the four stages of wheat (e.g., 40/40/40/40 denotes targeting 40\% potential crop ET $\left(E T_{c}\right)$ level at planting to dormancy, green up to booting, booting to flowering, and flowering to maturity, respectively) or at the two stages of maize (e.g., 40/40 denotes targeting $40 \%$ ET $_{c}$ level at planting to silking and at silking to maturity, respectively) based on long-term simulations with RZWQM under the no water limit condition, under 400, 300, 200, and $100 \mathrm{~mm}$ seasonal water available levels for wheat, and under 200 , 150, 100 , and $50 \mathrm{~mm}$ seasonal water available levels for maize.

\begin{tabular}{|c|c|c|c|c|c|c|}
\hline Crop & $\begin{array}{l}\text { Water Limit } \\
(\mathrm{mm})\end{array}$ & $\begin{array}{c}\text { Targeted } \mathrm{ET}_{c} \text { Levels } \\
(\%)\end{array}$ & $\begin{array}{l}\text { Irrigation } \\
(\mathrm{mm})\end{array}$ & $\begin{array}{c}\mathrm{GY} \\
\left(\mathrm{kg} \mathrm{ha}^{-1}\right)\end{array}$ & $\begin{array}{c}\text { ET } \\
(\mathrm{mm})\end{array}$ & $\begin{array}{c}\text { WUE } \\
\left(\mathrm{kg} \mathrm{ha}^{-1} \mathrm{~mm}^{-1}\right)\end{array}$ \\
\hline \multirow[t]{9}{*}{ Wheat } & No limit & $100 / 100 / 100 / 100$ & 502 & 4751 & 621 & 7.7 \\
\hline & & $100 / 100 / 100 / 40$ & 411 & 4751 & 561 & 8.5 \\
\hline & & $40 / 100 / 100 / 40$ & 348 & 4500 & 499 & 9.1 \\
\hline & & $40 / 100 / 80 / 40$ & 320 & 4367 & 475 & 9.3 \\
\hline & & $40 / 80 / 80 / 40)$ & 294 & 3976 & 449 & 8.9 \\
\hline & 400 & $40 / 100 / 100 / 40$ & 336 & 4476 & 489 & 9.2 \\
\hline & 300 & $40 / 100 / 100 / 40$ & 289 & 4299 & 454 & 9.5 \\
\hline & 200 & $40 / 100 / 100 / 40$ & 196 & 3271 & 379 & 8.6 \\
\hline & 100 & $40 / 100 / 100 / 40$ & 96 & 1700 & 287 & 5.8 \\
\hline \multirow[t]{7}{*}{ Maize } & No limit & $100 / 100$ & 173 & 5716 & 402 & 14.2 \\
\hline & & $100 / 60,100 / 80$ & 165 & 5715 & 401 & 14.3 \\
\hline & & $80 / 80,80 / 60$ & 140 & 5629 & 390 & 14.4 \\
\hline & 200 & $100 / 40,100 / 60,100 / 80$ & 141 & 5603 & 389 & 14.3 \\
\hline & 150 & $80 / 100$ & 118 & 5486 & 382 & 14.3 \\
\hline & 100 & $60 / 100$ & 87 & 5229 & 368 & 14.1 \\
\hline & 50 & $100 / 40,100 / 60,100 / 80$ & 47 & 4905 & 347 & 13.9 \\
\hline
\end{tabular}

across seasons with no water limit increased from 175 and $328 \mathrm{~mm}$ for the $40 / 40 / 40 / 40$ irrigation scenario to 504 and $625 \mathrm{~mm}$, respectively, for the 100/100/100/100 irrigation scenario (figs. $3 \mathrm{c}$ and $3 \mathrm{~d}$ ). The simulated irrigation requirements reached $200 \mathrm{~mm}$ with targeted $\mathrm{ET}_{c}$ levels of 40/60/60/40, $300 \mathrm{~mm}$ with targeted levels higher than $80 \%$ $\mathrm{ET}_{c}$ at two of the four growth stages, and $400 \mathrm{~mm}$ with targeted levels higher than $60 \% \mathrm{ET}_{c}$ at all four growth stages (fig. 3c). The simulated irrigation requirement and ET for high targeted $\mathrm{ET}_{c}$ levels were generally higher than the values measured in field experiments (Fang et al., 2007; Zhang et al., 2006) and simulated under uniform irrigation management in the area (Chen et al., 2010; Fang et al., 2010b, 2013). One main reason for the discrepancy was the high soil water content across the seasons with high irrigation levels and short irrigation intervals (five days), which resulted in high soil evaporation, especially during early and later growth stages. For example, targeting $\mathrm{ET}_{c}$ levels of 100/40/40/100 with $328 \mathrm{~mm}$ of irrigation resulted in soil evaporation of $188 \mathrm{~mm}$, while targeting $\mathrm{ET}_{c}$ levels of 40/100/80/40 with $322 \mathrm{~mm}$ of irrigation produced only $147 \mathrm{~mm}$ of soil evaporation. The corresponding crop yield and WUE were, respectively, $2070 \mathrm{~kg} \mathrm{ha}^{-1}$ and $4.6 \mathrm{~kg} \mathrm{ha}^{-1} \mathrm{~mm}^{-1}$ for $100 / 40 / 40 / 100$ and $4450 \mathrm{~kg} \mathrm{ha}^{-1}$ and $9.4 \mathrm{~kg} \mathrm{ha}^{-1} \mathrm{~mm}^{-1}$ for $40 / 100 / 100 / 40$. Avoiding high irrigation levels at the early (P-D) and later (S-M) growth stages can reduce soil evaporation and improve WUE (fig. 3b), which is consistent with the results of field experiments in the study area (Fang et al., 2007; Zhang et al., 2004) and other semiarid areas (Kang et al., 2002).

Because the simulated average WUE across the wheat seasons also increased more rapidly (close contour lines) with the targeted $\mathrm{ET}_{c}$ levels at the G-B stage than at the B-F stage and decreased less with the targeted $\mathrm{ET}_{c}$ level at the $\mathrm{P}$ D stage than at the F-M stage, WUE reached a maximum value at the targeted $\mathrm{ET}_{c}$ levels of 40/100/80/40 (fig. 3b). This result was mainly due to the higher response of grain yield to irrigation at the G-B stage than at the B-F stage (fig. 3a) and the smaller amount of irrigation required to meet the targeted $\mathrm{ET}_{c}$ levels at the P-D stage than at the F-M stage (fig. 3c). The above simulation results (figs. 3a and 3b) indicate the competing goals for obtaining the highest wheat yield and WUE under the no water limit condition. This result was mainly due to the different responses of crop yield and WUE to ET, as confirmed by the results of field experiments in the study area (Zhang et al., 2004, 2013; Fang et al., 2007) and other semiarid regions (Xue et al., 2014).

To cope with the increased water deficit and groundwater crisis in the North China Plain, higher WUE along with suboptimal grain yield and reduced irrigation amounts was preferred when optimizing irrigation schedules for wheat (Fang et al., 2010b; Du et al., 2015). When deficit irrigation occurred at one, two, three, and all four growth stages of
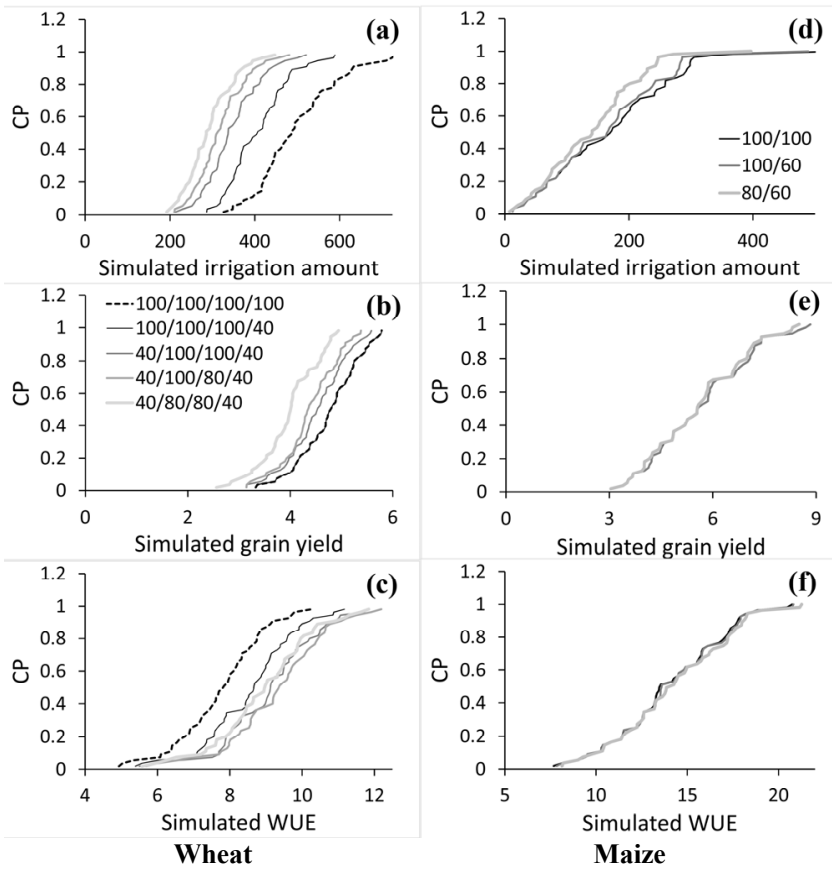

Figure 4. Cumulative probabilities (CP) for (a and d) simulated irrigation amount ( $\mathrm{mm})$, (b and e) grain yield $\left(\mathrm{Mg} \mathrm{ha}^{-1}\right)$, and (c and f) water use efficiency (WUE, $\mathrm{kg} \mathrm{ha}^{-1} \mathrm{~mm}^{-1}$ ) for 1958 to 2015 for the selected most reasonable irrigation targets levels (table 6 ) under no water limits. 
wheat, the most reasonable targeted $\mathrm{ET}_{c}$ levels with the highest WUE and suboptimal yield across seasons were 100/100/100/40, 40/100/100/40, 40/100/80/40, and 40/80/ $80 / 40$, respectively (table 6 ). The irrigation requirements below $400 \mathrm{~mm}$ occurred in $47 \%, 78 \%, 89 \%$, and $95 \%$ of the simulated seasons from 1958 to 2015 , respectively, for these four irrigation scenarios (fig. 4a). The 100/100/ 100/100 irrigation scenario resulted in irrigation requirements higher than $400 \mathrm{~mm}$ in $89 \%$ of simulated seasons (fig. $4 \mathrm{a}$ ). The $100 / 100 / 100 / 40$ irrigation scenario compared with the $100 / 100 / 100 / 100$ irrigation scenario produced the same average grain yield (4750 vs. $4750 \mathrm{~kg} \mathrm{ha}^{-1}$ ) but higher WUE (8.5 vs. $7.7 \mathrm{~kg} \mathrm{ha}^{-1} \mathrm{~mm}^{-1}$ ) with lower irrigation amounts (411 vs. $502 \mathrm{~mm}$ ) across the seasons (figs. $4 \mathrm{a}, 4 \mathrm{~b}$, and $4 \mathrm{c}$ ). The simulated WUE increased further for the 40/100/100/40 and $40 / 100 / 80 / 40$ irrigation scenarios compared with the $100 / 100 / 100 / 40$ scenario, with reduced grain yield and irrigation amounts across the seasons (table 6 and figs. $4 a, 4 b$, and $4 \mathrm{c}$ ). All of the above irrigation scenarios produced grain yields higher than $4000 \mathrm{~kg} \mathrm{ha}^{-1}$ in more than $79 \%$ of simulated seasons and WUE higher than $8.0 \mathrm{~kg} \mathrm{ha}^{-1} \mathrm{~mm}^{-1}$ in more than $48 \%$ of simulated seasons (figs. $4 \mathrm{~b}$ and $4 \mathrm{c}$ ). Deficit irrigation at all four growth stages (40/80/80/40) produced wheat yields lower than $4000 \mathrm{~kg} \mathrm{ha}^{-1}$ in $50 \%$ of simulation seasons but higher WUE values than the 100/100/100/40 irrigation scenario (figs. $4 b$ and $4 c$ ).

\section{Limited Seasonal Water Availabilities}

Similar to the no water limit condition (figs. $3 \mathrm{a}, 3 \mathrm{c}$, and $3 \mathrm{~d}$ ), the highest average grain yield, irrigation amount, and ET were also simulated with the highest targeted $\mathrm{ET}_{c}$ levels at all four growth stages (figs. 5a, 5c, and 5d). The simulated average WUE was also maximized with the highest targeted $\mathrm{ET}_{c}$ levels at both the G-B and B-F stages and with the lowest targeted $\mathrm{ET}_{c}$ levels at both the P-D and F-M stages, which were close to the no water limit condition when targeting the same $\mathrm{ET}_{c}$ levels at these stages (fig. 5b vs. fig. 3b). When targeting $60 \%$ or higher $\mathrm{ET}_{c}$ levels at the P-D or F-M stage, the simulated average WUE values were generally higher with less simulated irrigation amount and ET with the $400 \mathrm{~mm}$ water limit (figs. 5b, 5c, and 5d) compared with the no water limit condition (figs. 3b, 3c, and 3d). The most reasonable irrigation scenario was 40/100/100/40, which produced a suboptimal average wheat yield of $4476 \mathrm{~kg} \mathrm{ha}^{-1}$ but the highest WUE of $9.2 \mathrm{~kg} \mathrm{ha}^{-1} \mathrm{~mm}^{-1}$ and irrigation amounts of $336 \mathrm{~mm}$ (table 6).
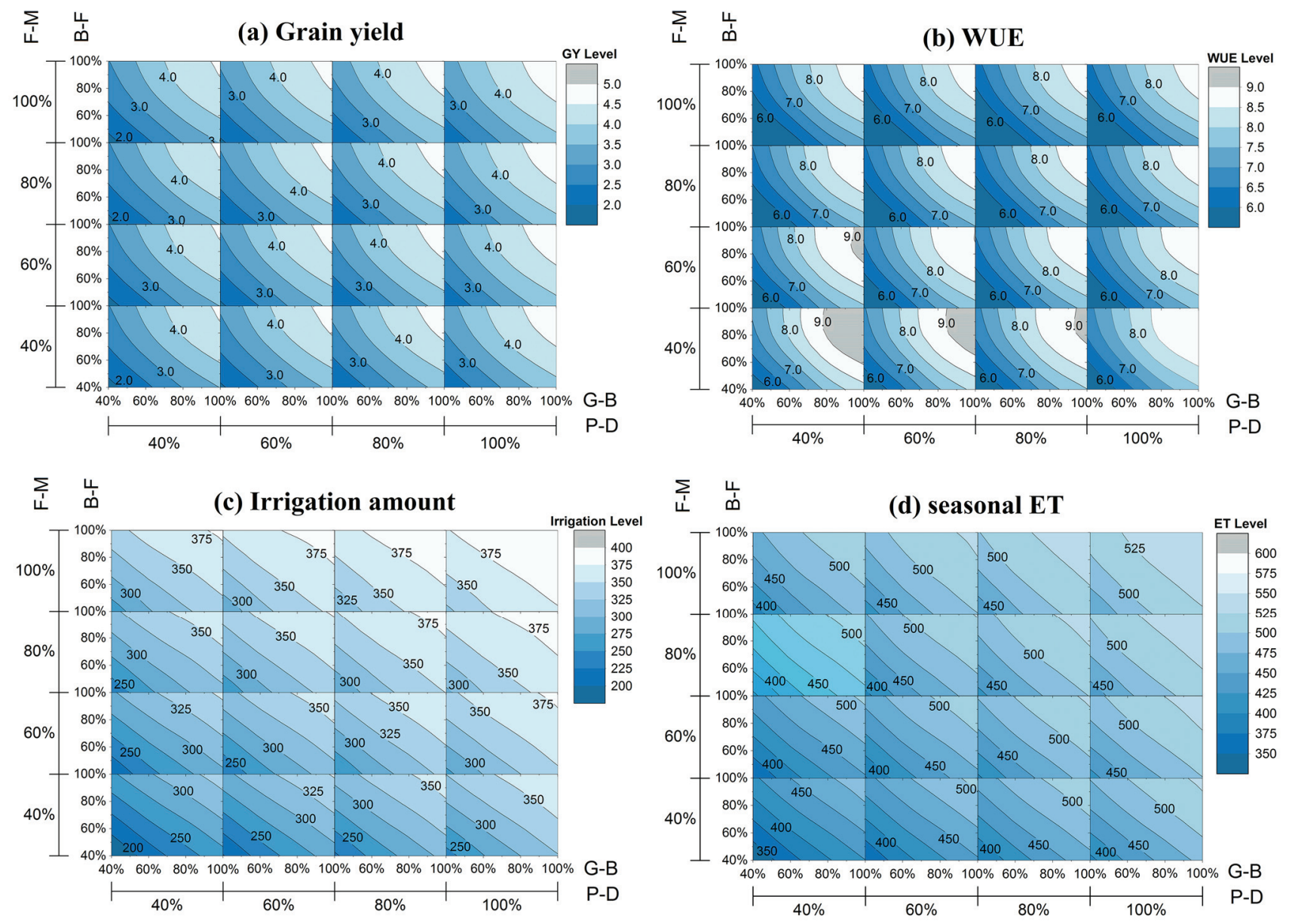

Figure 5. Responses of averaged (a) crop grain yield $\left(\mathrm{GY}, \mathrm{Mg} \mathrm{ha}^{-1}\right)$, (b) water use efficiency (WUE, $\left.\mathrm{kg} \mathrm{ha}^{-1} \mathrm{~mm}^{-1}\right)$, (c) irrigation amount (mm), and (d) evapotranspiration (ET, $\mathrm{mm}$ ) across seasons to the various targeted potential crop ET levels $\left(40 \%\right.$ to $100 \% \mathrm{ET}_{c}$ ) at the four growth stages of wheat ( $P$-D = planting to dormancy, G-B = green up to booting, $B-F=$ booting to flowering, and F-M = flowering to maturity) based on long-term simulations for 1958 to 2015 under the $400 \mathrm{~mm}$ water limit condition. 

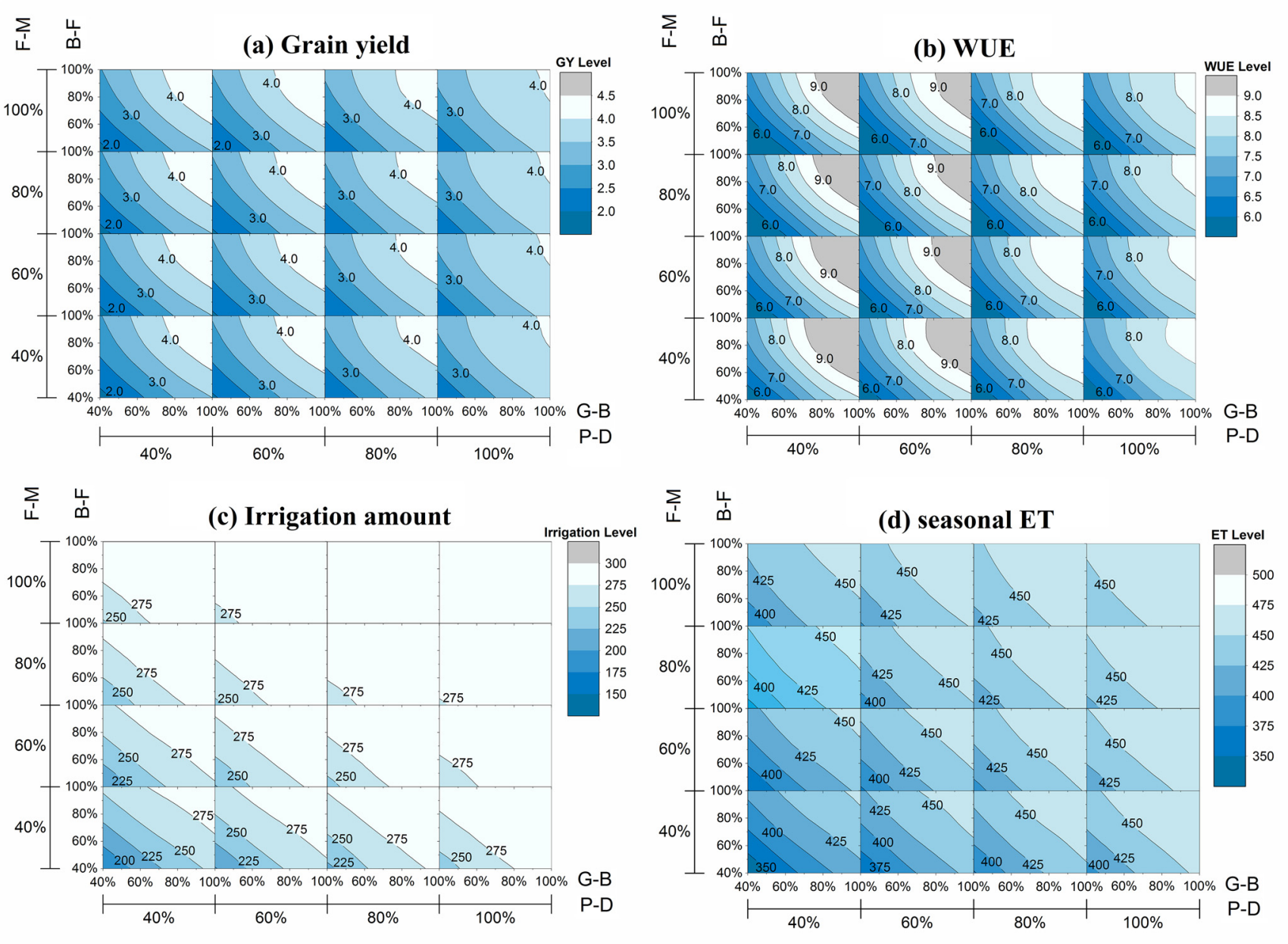

Figure 6. Responses of averaged (a) crop grain yield (GY, Mg ha-1), (b) water use efficiency (WUE, $\left.\mathrm{kg} \mathrm{ha}^{-1} \mathrm{~mm}^{-1}\right)$, (c) irrigation amount (mm), and (d) evapotranspiration (ET, $\mathrm{mm})$ across seasons to the various targeted potential crop ET levels (40\% to $100 \%$ ET $)$ at the four growth stages of wheat ( $\mathrm{P}-\mathrm{D}=$ planting to dormancy, $\mathrm{G}-\mathrm{B}=$ green up to booting, $\mathrm{B}-\mathrm{F}=$ booting to flowering, and $\mathrm{F}-\mathrm{M}=\mathrm{flowering}$ to $\mathrm{maturity}) \mathrm{based}$ on long-term simulations for 1958 to 2015 under the $300 \mathrm{~mm}$ water limit condition.

With $300 \mathrm{~mm}$ seasonal water limits (fig. 6a), average grain yield higher than $4000 \mathrm{~kg} \mathrm{ha}^{-1}$ was simulated with targeted $\mathrm{ET}_{c}$ levels higher than $80 \%$ at both the G-B and B-F stages. However, the highest average WUE values $(>9.0 \mathrm{~kg}$ $\mathrm{ha}^{-1} \mathrm{~mm}^{-1}$ ) were generally higher than that with the $400 \mathrm{~mm}$ water limit (fig. $5 \mathrm{~b}$ vs. fig. $6 \mathrm{~b}$ ). Different from the no limit and $400 \mathrm{~mm}$ water limit conditions (figs. 3 and 5), the simulated highest average grain yield and WUE were coincident with the highest targeted $\mathrm{ET}_{c}$ levels at the G-B and B-F stages and the lowest targeted $\mathrm{ET}_{c}$ levels at the P-D stage (figs. 6a and 6b). The $200 \mathrm{~mm}$ seasonal water limit can only meet the targeted $\mathrm{ET}_{c}$ levels of 40/60/60/40 and 40/40/40/40 according to the simulated irrigation requirement with no water limit (fig. 3c). The simulated grain yield and WUE were also maximized when the high targeted $\mathrm{ET}_{c}$ levels were at both the G-B and B-F stages. The $100 \mathrm{~mm}$ seasonal water limit, which was inadequate to meet the lowest targeted $\mathrm{ET}_{c}$ levels of 40/40/40/40 (fig. 3c), resulted in the lowest average grain yield (1354 to $1734 \mathrm{~kg} \mathrm{ha}^{-1}$ ) and WUE (4.5 to $5.7 \mathrm{~kg}$ $\mathrm{ha}^{-1} \mathrm{~mm}^{-1}$ ), with little or no response to these targeted $\mathrm{ET}_{c}$ levels. The most reasonable targeted irrigation scenarios were 40/100/100/40 with deficit irrigation at early and later growth stages, which produced both the highest average wheat yield and WUE values of, respectively, $4299 \mathrm{~kg} \mathrm{ha}^{-1}$ and $9.5 \mathrm{~kg} \mathrm{ha}^{-1} \mathrm{~mm}^{-1}$ for the $300 \mathrm{~mm}$ water limit, $3271 \mathrm{~kg}$ $\mathrm{ha}^{-1}$ and $8.6 \mathrm{~kg} \mathrm{ha}^{-1} \mathrm{~mm}^{-1}$ for the $200 \mathrm{~mm}$ water limit, and $1734 \mathrm{~kg} \mathrm{ha}^{-1}$ and $5.7 \mathrm{~kg} \mathrm{ha}^{-1} \mathrm{~mm}^{-1}$ for the $100 \mathrm{~mm}$ water limit (table 6). Field experiments (Zhang et al., 2006; Bian et al., 2016) and long-term model simulations (Fang et al., 2010b; Chen et al., 2010) also showed that scheduling limited irrigations from early stages to middle stages of wheat increased grain yield and WUE in the area. Quantifying the responses of crop yield, WUE, irrigation amount, and ET to the various targeted $\mathrm{ET}_{c}$ levels at different growth stages (figs. 3 through 6) could be used to develop ET-based irrigation decision support systems for better managing the limited irrigation water and achieving higher WUE in the area.

\section{OPTIMIZING ET-BASED IRRIGATION SCHEDULING in Maize Seasons \\ Unlimited Seasonal Water A vailability}

The simulated maize yield and WUE were more sensitive to irrigation at the P-S stage than at the S-M stage (fig. 2), which indicates that maize was more sensitive to water stress in the early growth period (P-S stage). The high targeted $\mathrm{ET}_{c}$ level at the P-S stage also reduced the seasonal variations in simulated maize yield and WUE (fig. 2). Little or no reduction in simulated average yield by targeted $\mathrm{ET}_{c}$ levels lower 
than $100 \%$ at the S-M stage was mainly due to the high rainfall during this period (186 mm for August and September; table 1) and the high soil water content during the previous P-S stage (174 mm for July; table 1). The reasonable targeted $\mathrm{ET}_{c}$ levels for higher yield and WUE were at or above $80 \%$ $\mathrm{ET}_{c}$ for the P-S growth stage and below $80 \% \mathrm{ET}_{c}$ for the $\mathrm{S}-\mathrm{M}$ growth stage. Previous studies reported that irrigation at maize planting was required under low initial soil water conditions in the area (Zhang et al., 2006; Fang et al., $2010 \mathrm{~b}$ ), and irrigation during later growth periods caused little increase in maize yield due to adequate seasonal rainfall in the area (Zhang et al., 2006). However, in semiarid areas with limited seasonal rainfall, meeting crop water requirements during the reproductive stages is very important for obtaining higher yield and WUE (Domínguez et al., 2012; Fang et al., 2014b). In northern Colorado, with seasonal rainfall of $161 \mathrm{~mm}$ (1992-2013), Fang et al. (2014b) explored maize yield responses to irrigation levels of $40 \%, 60 \%, 80 \%$, and $100 \% \mathrm{ET}_{c}$ from 1992 to 2013 and found that the highest grain yield and WUE were obtained for irrigation levels between the vegetative (before tasseling) and reproductive (after tasseling) stages of 100/100 for the no limit condition and $500 \mathrm{~mm}$ water limit, $80 / 100$ for $400 \mathrm{~mm}$ water limit, and $60 / 100$ for $300 \mathrm{~mm}$ water limit, respectively.

The simulated average grain yield, irrigation requirement, and ET across seasons (1958 to 2015) increased from 5175 $\mathrm{kg} \mathrm{ha}^{-1}, 93 \mathrm{~mm}$, and $363 \mathrm{~mm}$, respectively, at the 40/40 $\mathrm{ET}_{c}$ irrigation levels to $5716 \mathrm{~kg} \mathrm{ha}^{-1}, 173 \mathrm{~mm}$, and $402 \mathrm{~mm}$, respectively, at the $100 / 100 \mathrm{ET}_{c}$ irrigation levels. The simulated average irrigation requirements reached $100 \mathrm{~mm}$ with targeted $\mathrm{ET}_{c}$ levels of 40/60 and $150 \mathrm{~mm}$ with targeted $\mathrm{ET}_{c}$ levels of $80 / 80$, and the corresponding average grain yields were 5230 and $5629 \mathrm{~kg} \mathrm{ha}^{-1}$, respectively. The most suitable targeted $\mathrm{ET}_{c}$ levels with no water limit were 100/60 and $100 / 80$ with deficit irrigation only at the S-M stage and 80/60 and 80/80 with deficit irrigation at both the P-S and S-M stages (table 6 and fig. 4). Simulated irrigation amounts higher than $200 \mathrm{~mm}$ occurred in $22 \%, 33 \%$, and $38 \%$ of simulated seasons for the irrigation scenarios of 80/60, 100/60, and 100/100, respectively (fig. 4d). These irrigation scenarios produced similar grain yields and WUE values across the seasons (figs. 4e and 4f).

Compared with the wheat seasons, the simulated average maize yield and WUE increased less at the targeted $\mathrm{ET}_{c}$ levels, mainly due to the high seasonal rainfall (average rainfall of $411 \mathrm{~mm}$ ) but showed higher variations across seasons (fig. 2), indicating greater influence of weather variation on maize than on wheat in the area. Fang et al. (2013) also identified daily air temperature and radiation, not irrigation, as the most influencing factor for maize yield in the region. Irrigation management for maize should consider the high yearly variability in grain yield and WUE associated with weather variations, as shown in figs. $4 \mathrm{~d}, 4 \mathrm{e}$, and $4 \mathrm{f}$.

\section{Limited Seasonal Water Availabilities}

Similar to the no water limit condition, the selected reasonable targeted $\mathrm{ET}_{c}$ levels were also higher at the P-S stage $(80 \%$ to $100 \% \mathrm{ET}_{c}$ ) than at the S-M stage (40\% to $80 \% \mathrm{ET}_{c}$ ) for the $200 \mathrm{~mm}$ water limit and produced slightly lower maize yield with lower irrigation amounts (table 6). However, with the 150 and $100 \mathrm{~mm}$ seasonal water limits, the most reasonable targeted $\mathrm{ET}_{c}$ levels for maize were $80 \%$ to $60 \% \mathrm{ET}_{c}$ at the $\mathrm{P}-$ $\mathrm{S}$ stage and $100 \% \mathrm{ET}_{c}$ at the $\mathrm{S}-\mathrm{M}$ stage (table 6). Under the 50 $\mathrm{mm}$ water limit, the most reasonable irrigation levels were consistent with no limit and $200 \mathrm{~mm}$ water limit (table 6). This result indicates that reasonable water stress levels (targeted $\mathrm{ET}_{c}$ levels) between the two growth stages of maize varied with the different irrigation water constraints in the area.

\section{CONCLUSIONS}

Compared to a field lysimeter study, the model calibration resulted in acceptable simulation of daily ET, soil water, and grain yield across seasons from 1998 to 2003. These results were generally comparable with previous simulation studies in the area. For the long-term simulations with the calibrated model, the simulated average crop yield, WUE, irrigation amount, and ET responded less to irrigation in the maize seasons than in the wheat seasons. The most sensitive growth stages to water stress were from green up to flowering for wheat (middle growth stages) and from planting to silking for maize (early growth stages) in the area. The highest wheat yield across the seasons was simulated with the highest targeted $\mathrm{ET}_{c}$ levels at all four growth stages under no limit and $400 \mathrm{~mm}$ water limit conditions. Under 300 and $200 \mathrm{~mm}$ water limits, however, the highest wheat yield was obtained with the highest targeted $\mathrm{ET}_{c}$ level at both the G-B and $\mathrm{B}-\mathrm{F}$ stages and with lower targeted $\mathrm{ET}_{c}$ level at the P-D stage. The highest average wheat WUE across the seasons was simulated with the highest targeted $\mathrm{ET}_{c}$ levels at both the G-B and B-F stages and with the lowest targeted $\mathrm{ET}_{c}$ levels at the P-D stage for all water constraints. When obtaining higher WUE is a top priority to cope with the severe irrigation water deficits in the region, the most suitable ET-based irrigation schedules for wheat are recommended as $40 / 100 / 100 / 40$ for the $400,300,200$, and $100 \mathrm{~mm}$ water limits, with irrigation amounts of 336, 289, 196, and $96 \mathrm{~mm}$, respectively. During the maize seasons, higher targeted ET levels at the P-S stage ( $80 \%$ to $\left.100 \% \mathrm{ET}_{c}\right)$ than at the S-M stage $\left(40 \%\right.$ to $\left.80 \% \mathrm{ET}_{c}\right)$ are recommended for obtaining high grain yield and WUE, with corresponding irrigation amounts ranging from 47 to $173 \mathrm{~mm}$ for all water limit conditions.

The currently optimized ET-based irrigation schedules from the long-term model simulations accounted for crop water requirement and crop responses to water stress and timing (selected growth stages) across or within seasons. The advantage of ET-based irrigation scheduling over uniform irrigation scheduling make this method applicable in precision irrigation using real-time weather information (Vellidis et al., 2016). Other simple PET estimation methods, such as the Penman-Monteith equation, can be more practical for developing ET-based irrigation schedules, but they require real-time data on crop growth parameters (crop coefficient) and soil water status, which are usually unavailable or difficult to obtain. On the other hand, ET-based irrigation with small irrigation intervals (five days in the study) may induce high soil evaporation, especially at high targeted 
ET levels, and require more labor and cash inputs. Under this condition, sprinkler or drip irrigation is needed to handle the small irrigation amounts. ET-based irrigation may not be reasonable during early growth stages with high soil evaporation and low crop transpiration. Because ET-based irrigation scheduling does not account for soil water status, future research should consider combining this method with soil water stress indictors to derive irrigation schedules from crop growth simulations.

\section{ACKNOWLEDGEMENTS}

This work was supported in part by the National Natural Science Foundation of China (31671627), the CAS "Light of West China" Program, and the National Key Research and Development Program (2016YFD0300105-1 and 2016 YFD03008-3).

\section{REFERENCES}

Ahuja, L. R., Cassel, D. K., Bruce, R. R., \& Barnes, B. B. (1989). Evaluation of spatial distribution of hydraulic conductivity using effective porosity data. Soil Sci., 148(6), 404-411.

Allen, R. G., Pereira, L. S., Howell, T. A., \& Jensen, M. E. (2011). Evapotranspiration information reporting: I. Factors governing measurement accuracy. Agric. Water Mgmt., 98(6), 899-920. https://doi.org/10.1016/j.agwat.2010.12.015

Araya, A., Kisekka, I., Prasad, V., Holman, J., Foster, A., \& Lollato, R. (2017). Assessing wheat yield, biomass, and water productivity responses to growth stage based irrigation water allocation. Trans. ASABE, 60(1), 107-121. https://doi.org/10.13031/trans.11883

Aydinsakir, K., Erdal, S., Buyuktas, D., Bastug, R., \& Toker, R. (2013). The influence of regular deficit irrigation applications on water use, yield, and quality components of two corn (Zea mays L.) genotypes. Agric. Water Mgmt., 128, 65-71. https://doi.org/10.1016/j.agwat.2013.06.013

Bian, C., Ma, C., Liu, X., Gao, C., Liu, Q., Yan, Z., ... Li, Q. (2016). Responses of winter wheat yield and water use efficiency to irrigation frequency and planting pattern. PLoS One, 11(5), e0154673. https://doi.org/10.1371/journal.pone.0154673

Blanke, A., Rozelle, S., Lohmar, B., Wang, J., \& Huang, J. (2007). Water saving technology and saving water in China. Agric. Water Mgmt., 87(2), 139-150. https://doi.org/10.1016/j.agwat.2006.06.025

Brooks, R. H., \& Corey, A. T. (1964). Hydraulic properties of porous media: Hydrology papers. Fort Collins, CO: Colorado State University.

Chen, C., Wang, E., \& Yu, Q. (2010). Modeling the effects of climate variability and water management on crop water productivity and water balance in the North China Plain. Agric. Water Mgmt., 97(8), 1175-1184. https://doi.org/10.1016/j.agwat.2008.11.012

Djaman, K., \& Irmak, S. (2012). Soil water extraction patterns and crop, irrigation, and evapotranspiration water use efficiency of maize under full and limited irrigation and rainfed settings. Trans. ASABE, 55(4), 1223-1238. https://doi.org/10.13031/2013.42262

Dominguez, A., De Juan, J. A., Tarjuelo, J. M., Martinez, R. S., \& Martinez-Romero, A. (2012). Determination of optimal regulated deficit irrigation strategies for maize in a semi-arid environment. Agric. Water Mgmt., 110, 67-77. https://doi.org/10.1016/j.agwat.2012.04.002

Du, T., Kang, S., Zhang, J., \& Davies, W. J. (2015). Deficit irrigation and sustainable water-resource strategies in agriculture for China's food security. J. Exp. Botany, 66(8), 2253-2269. https://doi.org/10.1093/jxb/erv034

Fang, Q. X., Ma, L., Flerchinger, G. N., Qi, Z., Ahuja, L. R., Xing, H. T., ... Yu, Q. (2014a). Modeling evapotranspiration and energy balance in a wheat-maize cropping system using the revised RZ-SHAW model. Agric. Forest Meteorol., 194, 218229. https://doi.org/10.1016/j.agrformet.2014.04.009

Fang, Q. X., Ma, L., Green, T. R., Yu, Q., Wang, T. D., \& Ahuja, L. R. (2010a). Water resources and water use efficiency in the North China Plain: Current status and agronomic management options. Agric. Water Mgmt., 97(8), 1102-1116. https://doi.org/10.1016/j.agwat.2010.01.008

Fang, Q. X., Ma, L., Nielsen, D. C., Trout, T. J., \& Ahuja, L. R. (2014b). Quantifying corn yield and water use efficiency under growth stage-based deficit irrigation conditions. In L. R. Ahuja, L. Ma, \& R. J. Lascano (Eds.), Practical applications of agricultural system models to optimize the use of limited water (pp. 1-24). Madison, WI: ASA, SSSA, CSSA. https://doi.org/10.2134/advagricsystmodel5.c1

Fang, Q. X., Ma, L., Yu, Q., Hu, C. S., Li, X. X., Malone, R. W., \& Ahuja, L. R. (2013). Quantifying climate and management effects on regional crop yield and nitrogen leaching in the North China Plain. J. Environ. Qual., 42(5), 1466-1479. https://doi.org/10.2134/jeq2013.03.0086

Fang, Q., Chen, Y., Yu, Q., Ouyang, Z., Li, Q., \& Yu, S. (2007). Much improved irrigation use efficiency in an intensive wheatmaize double cropping system in the North China Plain. J. Integ. Plant Biol., 49(10), 1517-1526. https://doi.org/10.1111/j.16729072.2007.00559.x

Fang, Q., Ma, L., Yu, Q., Ahuja, L. R., Malone, R. W., \& Hoogenboom, G. (2010b). Irrigation strategies to improve the water use efficiency of wheat-maize double cropping systems in North China Plain. Agric. Water Mgmt., 97(8), 1165-1174. https://doi.org/10.1016/j.agwat.2009.02.012

Fereres, E., \& Soriano, M. A. (2007). Deficit irrigation for reducing agricultural water use. J. Exp. Botany, 58(2), 147-159. https://doi.org/10.1093/jxb/erl165

Geerts, S., \& Raes, D. (2009). Deficit irrigation as an on-farm strategy to maximize crop water productivity in dry areas. Agric. Water Mgmt., 96(9), 1275-1284. https://doi.org/10.1016/j.agwat.2009.04.009

Geerts, S., Raes, D., \& Garcia, M. (2010). Using AquaCrop to derive deficit irrigation schedules. Agric. Water Mgmt., 98(1), 213-216. https://doi.org/10.1016/j.agwat.2010.07.003

Gheysari, M., Sadeghi, S.-H., Loescher, H. W., Amiri, S., Zareian, M. J., Majidi, M. M., ... Payero, J. O. (2017). Comparison of deficit irrigation management strategies on root, plant growth, and biomass productivity of silage maize. Agric. Water Mgmt., 182, 126-138. https://doi.org/10.1016/j.agwat.2016.12.014

He, J., Cai, H., \& Bai, J. (2013). Irrigation scheduling based on CERES-Wheat model for spring wheat production in the Minqin oasis in northwest China. Agric. Water Mgmt., 128, 19-31. https://doi.org/10.1016/j.agwat.2013.06.010

Hedley, C. B., \& Yule, I. J. (2009). A method for spatial prediction of daily soil water status for precise irrigation scheduling. Agric. Water Mgmt., 96(12), 1737-1745. https://doi.org/10.1016/j.agwat.2009.07.009

Kang, S., Hao, X., Du, T., Tong, L., Su, X., Lu, H., ... Ding, R. (2017). Improving agricultural water productivity to ensure food security in China under changing environment: From research to practice. Agric. Water Mgmt., 179, 5-17. https://doi.org/10.1016/j.agwat.2016.05.007

Kang, S., Zhang, L., Liang, Y., Hu, X., Cai, H., \& Gu, B. (2002). Effects of limited irrigation on yield and water use efficiency of 
winter wheat in the Loess Plateau of China. Agric. Water Mgmt., 55(3), 203-216. https://doi.org/10.1016/S0378-3774(01)00180-9

Kisekka, I., Aguilar, J. P., Rogers, D. H., Holman, J., O’Brien, D. M., \& Klocke, N. (2016). Assessing deficit irrigation strategies for corn using simulation. Trans. ASABE, 59(1), 303-317. https://doi.org/10.13031/trans.59.11206

Kloss, S., Pushpalatha, R., Kamoyo, K. J., \& Schutze, N. (2012). Evaluation of crop models for simulating and optimizing deficit irrigation systems in arid and semi-arid countries under climate variability. Water Resour. Mgmt., 26(4), 997-1014. https://doi.org/10.1007/s11269-011-9906-y

Li, J., Inanaga, S., Li, Z., \& Eneji, A. E. (2005). Optimizing irrigation scheduling for winter wheat in the North China Plain. Agric. Water Mgmt., 76(1), 8-23. https://doi.org/10.1016/j.agwat.2005.01.006

Liu, C., Jingiie, Y., \& Kendy, E. (2001). Groundwater exploitation and its impact on the environment in the North China Plain. Water Intl., 26(2), 265-272. https://doi.org/10.1080/02508060108686913

Liu, Y., \& Luo, Y. (2010). A consolidated evaluation of the FAO56 dual crop coefficient approach using the lysimeter data in the North China Plain. Agric. Water Mgmt., 97(1), 31-40. https://doi.org/10.1016/j.agwat.2009.07.003

Ma, L., Hoogenboom, G., Ahuja, L. R., Ascough, J. C., \& Saseendran, S. A. (2006). Evaluation of the RZWQM-CERESMaize hybrid model for maize production. Agric. Syst., 87(3), 274-295. https://doi.org/10.1016/j.agsy.2005.02.001

Ma, L., Trout, T. J., Ahuja, L. R., Bausch, W. C., Saseendran, S. A., Malone, R. W., \& Nielsen, D. C. (2012). Calibrating RZWQM2 model for maize responses to deficit irrigation. Agric. Water Mgmt., 103, 140-149. https://doi.org/10.1016/j.agwat.2011.11.005

Mansouri-Far, C., Sanavy, S. A. M. M., \& Saberali, S. F. (2010). Maize yield response to deficit irrigation during low-sensitive growth stages and nitrogen rate under semi-arid climatic conditions. Agric. Water Mgmt., 97(1), 12-22. https://doi.org/10.1016/j.agwat.2009.08.003

Marsal, J., \& Stöckle, C. O. (2012). Use of CropSyst as a decision support system for scheduling regulated deficit irrigation in a pear orchard. Irrig. Sci., 30(2), 139-147. https://doi.org/10.1007/s00271-011-0273-5

Mbabazi, D., Migliaccio, K. W., Crane, J. H., Fraisse, C., Zotarelli, L., Morgan, K. T., \& Kiggundu, N. (2017). An irrigation schedule testing model for optimization of the Smartirrigation avocado app. Agric. Water Mgmt., 179, 390-400. https://doi.org/10.1016/j.agwat.2016.09.006

Nash, J. E., \& Sutcliffe, J. V. (1970). River flow forecasting through conceptual models Part I: A discussion of principles. J. Hydrol., 10(3), 282-290. https://doi.org/10.1016/0022-1694(70)90255-6

Rawls, W. J., Brakensiek, D. L., \& Saxton, K. E. (1982). Estimation of soil water properties. Trans. ASAE, 25(5), 1316-1320. https://doi.org/10.13031/2013.33720

Saseendran, S. A., Ahuja, L. R., Nielsen, D. C., Trout, T. J., \& Ma, L. (2008). Use of crop simulation models to evaluate limited irrigation management options for corn in a semiarid environment. Water Resour. Res., 44(7). https://doi.org/10.1029/2007WR006181

Scanlon, B. R., Faunt, C. C., Longuevergne, L., Reedy, R. C., Alley, W. M., McGuire, V. L., \& McMahon, P. B. (2012). Groundwater depletion and sustainability of irrigation in the U.S. High Plains and Central Valley. Proc. Natl. Acad. Sci., 109(24), 9320-9325. https://doi.org/10.1073/pnas.1200311109

Shuttleworth, W. J., \& Wallace, J. S. (1985). Evaporation from sparse crops: An energy combination theory. Qtly. J. Royal Meteorol. Soc., 111(469), 839-855. https://doi.org/10.1002/qj.49711146910
Steduto, P., Hsiao, T. C., Raes, D., \& Fereres, E. (2009). AquaCrop - The FAO crop model to simulate yield response to water: I. Concepts and underlying principles. Agron. J., 101(3), 426-437. https://doi.org/10.2134/agronj2008.0139s

Stöckle, C. O., \& James, L. G. (1989). Analysis of deficit irrigation strategies for corn using crop growth simulation. Irrig. Sci., 10(2), 85-98. https://doi.org/10.1007/bf00265686

Sun, H., Zhang, X., Wang, E., Chen, S., \& Shao, L. (2015). Quantifying the impact of irrigation on groundwater reserve and crop production: A case study in the North China Plain. European J. Agron., 70, 48-56. https://doi.org/10.1016/j.eja.2015.07.001

Tari, A. F. (2016). The effects of different deficit irrigation strategies on yield, quality, and water-use efficiencies of wheat under semi-arid conditions. Agric. Water Mgmt., 167, 1-10. https://doi.org/10.1016/j.agwat.2015.12.023

Vellidis, G., Liakos, V., Andreis, J. H., Perry, C. D., Porter, W. M., Barnes, E. M., ... Migliaccio, K. W. (2016). Development and assessment of a smartphone application for irrigation scheduling in cotton. Comput. Electron. Agric., 127, 249-259. https://doi.org/10.1016/j.compag.2016.06.021

Xiao, D., Tao, F., Liu, Y., Shi, W., Wang, M., Liu, F., ... Zhu, Z. (2013). Observed changes in winter wheat phenology in the North China Plain for 1981-2009. Intl. J. Biometeorol., 57(2), 275-285. https://doi.org/10.1007/s00484-012-0552-8

Xue, Q., Rudd, J. C., Liu, S., Jessup, K. E., Devkota, R. N., \& Mahano, J. R. (2014). Yield determination and water-use efficiency of wheat under water-limited conditions in the U.S. Southern High Plains. Crop Sci., 54(1), 34-47. https://doi.org/10.2135/cropsci2013.02.0108

Yang, J., Wan, S., Deng, W., \& Zhang, G. (2007). Water fluxes at a fluctuating water table and groundwater contributions to wheat water use in the lower Yellow River flood plain, China. Hydrol. Proc., 21(6), 717-724. https://doi.org/10.1002/hyp.6246

Yu, Q., Saseendran, S. A., Ma, L., Flerchinger, G. N., Green, T. R., \& Ahuja, L. R. (2006). Modeling a wheat-maize double cropping system in China using two plant growth modules in RZWQM. Agric. Syst., 89(2), 457-477. https://doi.org/10.1016/j.agsy.2005.10.009

Zhang, H., \& Oweis, T. (1999). Water-yield relations and optimal irrigation scheduling of wheat in the Mediterranean region. Agric. Water Mgmt., 38(3), 195-211. https://doi.org/10.1016/S0378-3774(98)00069-9

Zhang, H., Wang, X., You, M., \& Liu, C. (1999). Water-yield relations and water-use efficiency of winter wheat in the North China Plain. Irrig. Sci., 19(1), 37-45. https://doi.org/10.1007/s002710050069

Zhang, X., Pei, D., Chen, S., Sun, H., \& Yang, Y. (2006). Performance of double-cropped winter wheat-summer maize under minimum irrigation in the North China Plain. Agron, J., 98(6), 1620-1626. https://doi.org/10.2134/agronj2005.0358

Zhang, X., Wang, Y., Sun, H., Chen, S., \& Shao, L. (2013). Optimizing the yield of winter wheat by regulating water consumption during vegetative and reproductive stages under limited water supply. Irrig. Sci., 31(5), 1103-1112. https://doi.org/10.1007/s00271-012-0391-8

Zhang, Y., Kendy, E., Qiang, Y., Changming, L., Yanjun, S., \& Hongyong, S. (2004). Effect of soil water deficit on evapotranspiration, crop yield, and water use efficiency in the North China Plain. Agric. Water Mgmt., 64(2), 107-122. https://doi.org/10.1016/S0378-3774(03)00201-4

Zwart, S. J., \& Bastiaanssen, W. G. (2004). Review of measured crop water productivity values for irrigated wheat, rice, cotton, and maize. Agric. Water Mgmt., 69(2), 115-133. https://doi.org/10.1016/j.agwat.2004.04.007 